\title{
Empirical evidence against U.S. H1-B visa restrictions, the case of employment in the manufacturing industry
}

\author{
by \\ Erjon Gjoci \\ Senior Research Analyst \\ Email: gjocierjon@gmail.com \\ Work: erjon.gjoci@ harrisx.com
}

\section{HarrisX a Stagwell Company}

1808 I Street NW

Floor 5

Washington, DC 20006
One World Trade Center

Floor 62

New York, NY 10003

Other authors: Not applicable 


\title{
Empirical evidence against U.S. H1-B visa restrictions, the case of employment in the manufacturing industry
}

\author{
Erjon Gjoci \\ Senior Research Analyst
}

\section{Abstract}

This empirical research paper provides ample evidence for policy makers to readdress the immigration policy--especially H1-B visa cap restrictions. The paper is focused on employment shifts and human capital achievement for two groups: the U.S. born and foreign-born working within the United States manufacturing industry. The manufacturing industry is the largest industry employer in the country, and it is in the brink of being at a disadvantage in the global stage due to labor shortage as the workforce ages. The paper uses data for three-year periods-2000, 2010, and 2019--from U.S. Census, The American Community Survey (ACS), Public Use Microdata Sample (PUMS) files, thus providing an overview in labor trends and the human capital needed for the industry to be competitive. The paper builds from the Mincer (1974) earnings function to determine hourly wages for the two groups and then uses the OaxacaBlinder (1973) method to measure potential bias between the U.S. born and foreign-born employees in the manufacturing industry. The results in this paper align with other recent research findings (Gest et al., 2021; Eckstein \& Peri, 2018) that show immigration as a tool to economic competitiveness. The data trends and findings in this paper synchronize with Borjas and Edo (2021) insights indicating that the native-born may respond to supply shocks of immigration by moving to other labor markets that are not directly affected by immigration.

Keywords: Wages, Mincer Equation, Oaxaca-Blinder, U.S. Immigration, Manufacturing, Industry, H1-B. 


\section{Introduction}

This research paper looks at the individual wages for two separate groups both employed in the manufacturing industry in the United States: the U.S. born and the foreign-born. After the selection of each group, the multiple linear regression is performed to determine the average hourly wages for three-year periods: 2000, 2010, and 2019. Year 2000 is the first year such data was made available and year 2019 is the last release from the U.S. Census.

The purpose of the paper is to determine whether there are earning differences between these two groups. The objective is to examine these differences for these three-year periods and then to determine whether higher rates of investment in human capital --years of education and skills- have resulted in higher wages or are the differences in earnings due to possible bias directed towards a particular group. Literature since 1982 (Borjas, 1982) and current reports (Gest et al., 2021) show that immigrants to the United States have higher incentives to improve their marketable skills. Both incentives and competitiveness results in higher efficiency and economic growth. The aging population and labor shortage in the manufacturing industry goes beyond, individual jobs, or, claims that immigration ousts domestic employment. S. Eckstein \& G. Peri (2018, p. 15) concluded that "high skilled immigrant niches contribute the most to the economy, even if they leave some highly qualified U.S.-born workers on the sidelines." Also, aligning with Borjas and Edo, the U.S. born also responds to any shocks from immigration by moving to other labor markets. Therefore, efficiency and economic growth ought to drive the immigration policy, thus enabling not only the manufacturers but other industries to be globally competitive and grow.

The analysis in this paper will point out whether there is any bias towards either of the two groups--U.S. born vs. foreign-born--and assess the literature that indicates that investment in human capital continues to drive economic growth using higher wages as a surrogate for economic growth. The goal of this analysis is that the findings be used by policy makers. Recent research finds that cap restrictions significantly reduce the hiring of new H1-B employees in forprofit firms (Mayda al., 2018). Also, recent survey data from the Philadelphia Federal Reserve Bank (2021) shows that manufacturing firms remain optimistic about growth, with one in three (33\%) of manufacturers expect increases (vs. 13\% expecting decrease) in general business 
activity. Thus, the need for the labor force is essential and these restrictions are very costly for the manufacturing industry in terms of sustainability and growth.

\section{I.1 Background}

U.S. Census data shows that in the manufacturing industry on average, the foreign-born employees' yearly wages are higher than the U.S. born employees by $\$ 1,565$ for $2000, \$ 2,387$ for 2010 , and $\$ 9,373$ for 2019 . The median yearly wages were higher for U.S. born by $\$ 2,037$, $\$ 1,008$ for the years 2000, 2010 respectively, and lower median wage of $\$ 2,020$ for the year 2019. See appendix 2 for more details. These differences can be attributed to the investment in human capital as illustrated by the higher median wages in the U.S. for 2000 and 2010 correlating with the distribution of education and experience among employees in the industry.

- $24 \%$ foreign-born had no-to-less than a high school compared to $9.8 \%$ U.S. born in the year 2000 --Table 2 (U.S. Census Bureau, 2000).

- $43.4 \%$ foreign-born had high-school and some college compared to $68.5 \%$ U.S. born in the year 2000 (U.S. Census Bureau, 2000). This group continues to be the largest group for the U.S. born employees in the manufacturing industry. Table 2 data section below for details for the other years and groups all showing similar correlation.

The two education groups discussed above--no schooling and those with some years of college-continue to be the largest portion of the employees for the manufacturing industry, making $71 \%$ of the total labor force for the U.S. born employees and $58.3 \%$ of the labor force for the U.S. born employees, thus this group determines the median wage earned --Table 2 (U.S. Census Bureau).

The econometric model contains 24 variables used in the OLS linear regression that include individual characteristics, potential experience, education, and occupation categories. The model methodology is based on Mincer earnings equation and human capital theory used by labor economists since 1958 (Mincer, 1958; Mincer, 1974; Heckman et al., 2003; Lemieux, 2006; Lagakos et al., 2018) The following methodology section of this paper elaborates further. After the equation has been established, then the analysis uses the Oaxaca-Blinder (1973) methodology to determine the differences and potential bias between the U.S. born and foreign-born civilians 
employed in the manufacturing industry in the United States. Building on these model foundations continues to be a benchmark for economist research.

Based on literary review, this is the first empirical research paper to apply the two models to employment in the manufacturing industry. The Sana Commerce commissioned 2021 Sapio Research study of digital transformation in manufacturing shows that a significant number of manufacturers will continue their long-term investment in digital strategies. Also, 94\% of manufacturers will need to change their market strategy due to the disruption faced from the pandemic in the year 2020. As a result of the evolution in the industry, the need for an expanded labor force--especially skilled labor--increases, and this paper concludes that the need for loosening visa restriction--particularly increasing the H1-B visa cap restrictions--will help the U.S. manufacturing industry's sustainability and competitiveness.

\section{Data \& Manufacturing Industry}

This paper examines employed private civilians in the manufacturing industry in the United States. The data used in this study is retrieved from the one-year American Community Survey (ACS) Public Use Microdata Sample (PUMS) from The U.S. Census Bureau for the three periods: 2000, 2010, and 2019. PUMS contains a sample of actual responses to the American Community Survey (ACS). Each record in the file represents a single person and contains data on approximately $1 \%$ of the United States population. For each of the three periods the analysis in this study looks at private employed civilians employed in the manufacturing industry. The 2019 U.S. Census PUMS dataset is the latest available. For this research we have selected the respondents between the age of 16 and 65 who have worked at least 40 weeks in the past 12 months and earn at least the minimum wage at the given year period: $\$ 5.15 /$ hour in the year 2000 and $\$ 7.25 /$ hour for the years 2010 and 2019. To perform the analysis in this paper, the data is separated into two sets: the U.S. born--excluding born to American people living abroad and/or born in U.S. territories--and foreign born who are the naturalized U.S. citizens in the country and excluding non-U.S. citizens. Table 1 below gives a mean summary of the individuals included in the data set for each year period studied; for complete summary statistics tables see Appendix 1. 
Table 1:

Manufacturing Industry: Mean of Respondent's Age, Weeks Worked, and Hours per Week.

\begin{tabular}{|c|c|c|c|c|c|c|}
\hline \multirow{2}{*}{$\begin{array}{l}\text { MEAN } \\
\text { SUMMARY }\end{array}$} & \multicolumn{3}{|c|}{ US BORN } & \multicolumn{3}{|c|}{ FOREIGN BORN } \\
\hline & 2000 & 2010 & 2019 & 2000 & 2010 & 2019 \\
\hline Respondent's Age & 41.44 & 44.97 & 44.58 & 43.28 & 46.74 & 48.50 \\
\hline $\begin{array}{l}\text { Weeks worked past } 12 \\
\text { months }\end{array}$ & 51.33 & 50.72 & 51.75 & 51.13 & 50.76 & 51.82 \\
\hline $\begin{array}{l}\text { Mean Hours worked per } \\
\text { week }\end{array}$ & 43.51 & 42.98 & 43.35 & 42.65 & 41.85 & 42.38 \\
\hline Sample Size (N) & 17,225 & 97,308 & 103,865 & 1,122 & 9,742 & 11,006 \\
\hline
\end{tabular}

*Data Source: U.S. Census: 2000, 2010, 2019 | Display \& Calculation: Author's own work.

*U.S. Census 2000: Release Date - June 10, 2004 | Author Retrieved: September 15, 2021

*U.S. Census 2010: Release Date - October 12, 2011 | Author Retrieved: September 15, 2021

*U.S. Census 2020: Release Date - October 15, 2020 | Author Retrieved: September 15, 2021

Table 1 shows that the average age for private civilians working in the manufacturing industry has increased over the twenty-year period at a higher rate than the U.S. population age increase overall of $2 \%$ reported by U.S. Census (2017), while the hours worked per week and weeks worked during the last 12 months remain about the same since the year 2000. The trend also indicates that the average age of foreign-born in the industry is higher than the U.S. born, representing a decline in the influx of immigrants over the past twenty years. A trend that could potentially harm the industry and slow the rate of economic growth. The next section discusses the methodology used to determine what are the effects that individual characteristics and human capital have on wages in the manufacturing industry.

\section{II.1. Manufacturing industry overview}

Employment in the manufacturing industry continues to be the largest industry when it comes to employed civilians in the labor force. According to the U.S. Census data:

- In the year $2000,20.2 \%$ of the whole private civilian labor force was employed in the manufacturing industry.

- In the year $2010,16.3 \%$ of the private civilian labor force was employed in the manufacturing industry

- In the year 2020, $15.0 \%$ of the private civilian labor force was employed in the manufacturing industry

The data shows a decline in terms of percentage of private civilian labor force employed in the industry, but still the manufacturing industry constitutes the largest percentage of the workforce 
among the other industries. The HealthCare industry follows closely at $14.9 \%$ in 2019 , up from $11.9 \%$ in the year 2000, refer to Appendix 2 for details.

\section{II.1.A. Education in the manufacturing industry}

Table 2 below shows the distribution of education attainment by degree type for the private civilian labor force in the manufacturing industry for the three U.S. Census periods, 2000, 2010, and 2019. 47.2\% of U.S. Born private civilians employed in the manufacturing industry have a high-school or less education attainment and $21.7 \%$ have bachelor's or higher degree in the year 2000 compared to $45.6 \%$ and $32.6 \%$ respectively of foreign born. In $2019,29.0 \%$ of U.S. born have a bachelor's or advanced degree compared to $41.7 \%$ of foreign born.

\section{Table 2:}

Private Employed Civilians in The Manufacturing Industry - Education Attainment by Degree

\begin{tabular}{|l|r|r|r|r|r|r|}
\hline \multirow{2}{*}{$\begin{array}{l}\text { EDUCATION ATTAINMENT } \\
\text { By DEGREE }\end{array}$} & \multicolumn{2}{|l|}{ US BORN } & \multicolumn{3}{l|}{ FOREIGN BORN } \\
\cline { 2 - 7 } & $\mathbf{2 0 0 0}$ & $\mathbf{2 0 1 0}$ & $\mathbf{2 0 1 9}$ & $\mathbf{2 0 0 0}$ & $\mathbf{2 0 1 0}$ & $\mathbf{2 0 1 9}$ \\
\hline No School & $0.2 \%$ & $0.3 \%$ & $0.5 \%$ & $1.8 \%$ & $4.1 \%$ & $4.5 \%$ \\
\hline Less than High School & $9.6 \%$ & $5.6 \%$ & $4.9 \%$ & $22.2 \%$ & $16.9 \%$ & $13.1 \%$ \\
\hline High School Diploma & $37.3 \%$ & $35.8 \%$ & $33.8 \%$ & $21.7 \%$ & $21.1 \%$ & $20.4 \%$ \\
\hline Some College/Associate Degree & $31.1 \%$ & $32.1 \%$ & $31.8 \%$ & $21.7 \%$ & $21.6 \%$ & $20.3 \%$ \\
\hline Bachelors & $16.4 \%$ & $19.1 \%$ & $21.3 \%$ & $18.8 \%$ & $19.2 \%$ & $21.9 \%$ \\
\hline Masters & $4.5 \%$ & $6.1 \%$ & $6.6 \%$ & $10.3 \%$ & $12.6 \%$ & $14.4 \%$ \\
\hline Professional & $0.3 \%$ & $0.4 \%$ & $0.5 \%$ & $0.6 \%$ & $0.9 \%$ & $1.0 \%$ \\
\hline Doctorate & $0.5 \%$ & $0.6 \%$ & $0.6 \%$ & $2.9 \%$ & $3.8 \%$ & $4.4 \%$ \\
\hline Sample Size (N) & 17,225 & 97,305 & 103,865 & 1,122 & 9,742 & 11,006 \\
\hline
\end{tabular}

*Data Source: U.S. Census: 2000, 2010, 2019 | Display \& Calculation: Author's own work.

*U.S. Census 2000: Updated - June 10, 2004 | Author Retrieved: September 15, 2021

*U.S. Census 2010: Updated - October 12, 2011 | Author Retrieved: September 15, 2021

*U.S. Census 2020: Updated - October 15, 2020 | Author Retrieved: September 15, 2021

Data shows that the gap in higher education attainment among the two groups continues to be significantly different - with the more than $10 \%$ of foreign-born individuals pursuing bachelors' or higher degrees. This trend points out that foreign born individuals are more likely to increase their human capital via education. Given the endless and needed evolution in the industries, an educated individual will be in a better position to be employed and/or earn higher wages, another reason which demonstrates the need to ease visa restrictions.

II.1.B. Employment roles in the manufacturing industry

Table 3 below shows the distribution of job role categories for both U.S. born and foreign-born employees in the manufacturing industry for the three time periods from the Census data years: 2000, 2010, and 2019. 
Table 3:

Private Employed Civilians in the Manufacturing Industry - Employment Role Categories

\begin{tabular}{|l|r|r|r|r|r|r|}
\hline \multirow{2}{*}{\begin{tabular}{l} 
EMPLOYMENT ROLE \\
\cline { 2 - 7 }
\end{tabular}} & \multicolumn{3}{|c|}{ US BORN } & \multicolumn{3}{|c|}{ FOREIGN BORN } \\
\hline MGR: Management Roles & $13.0 \%$ & $12.6 \%$ & $10.3 \%$ & $12.9 \%$ & $10.4 \%$ & $9.6 \%$ \\
\hline $\begin{array}{l}\text { CMM: Computer/ Machine } \\
\text { Operators }\end{array}$ & $3.0 \%$ & $2.9 \%$ & $2.8 \%$ & $5.5 \%$ & $4.9 \%$ & $5.4 \%$ \\
\hline ENGN: Engineering & $8.9 \%$ & $7.4 \%$ & $7.6 \%$ & $13.4 \%$ & $11.6 \%$ & $11.9 \%$ \\
\hline PRD: Production & $36.1 \%$ & $35.9 \%$ & $38.7 \%$ & $37.9 \%$ & $42.8 \%$ & $43.5 \%$ \\
\hline TRN: Transportation & $8.6 \%$ & $8.3 \%$ & $7.1 \%$ & $6.3 \%$ & $5.2 \%$ & $4.0 \%$ \\
\hline $\begin{array}{l}\text { OFF: Office/Administrative } \\
\text { Paperwork }\end{array}$ & $8.2 \%$ & $11.0 \%$ & $12.4 \%$ & $6.0 \%$ & $7.6 \%$ & $9.2 \%$ \\
\hline $\begin{array}{l}\text { OC_RA: Finance/ Business/ } \\
\text { Science Research \& Analysts }\end{array}$ & $11.5 \%$ & $11.0 \%$ & $10.2 \%$ & $10.8 \%$ & $9.7 \%$ & $10.0 \%$ \\
\hline Other Roles & $10.7 \%$ & $10.8 \%$ & $11.0 \%$ & $7.2 \%$ & $7.7 \%$ & $6.4 \%$ \\
\hline Sample Size (N) & 17,225 & 97,305 & 103,865 & 1,122 & 9,742 & 11,006 \\
\hline
\end{tabular}

*Data Source: U.S. Census: 2000, 2010, 2019 | Display \& Calculation: Author's own work.

*U.S. Census 2000: Release Date - June 10, 2004 | Author Retrieved: September 15, 2021

*U.S. Census 2010: Release Date - October 12, 2011 | Author Retrieved: September 15, 2021

*U.S. Census 2020: Release Date - October 15, 2020 | Author Retrieved: September 15, 2021

Table 3 shows that differences in the distribution of employment roles are smaller between the two groups than the differences in the education attainment from Table 2. The U.S. born have a slightly higher percentage when it comes to management and office administration related roles, while foreigners continue to maintain the lead in engineering and computer/machine operation job roles.

II.1.C. Average hourly wages in the manufacturing industry

Table 4 below shows the mean wage, standard no, and the median wage for the manufacturing industry for the three periods being studied.

Table 4:

Private Employed Civilians in The Manufacturing Industry - Employee Hourly Wage

\begin{tabular}{|l|r|r|r|r|r|r|}
\hline \multirow{2}{*}{$\begin{array}{c}\text { HOURLY WAGE } \\
\text { DESCRIPTIVE } \\
\text { STATISTICS }\end{array}$} & \multicolumn{3}{|c|}{ US BORN } & \multicolumn{3}{c|}{ FOREIGN BORN } \\
\cline { 2 - 7 } & $\mathbf{2 0 0 0}$ & $\mathbf{2 0 1 0}$ & $\mathbf{2 0 1 9}$ & $\mathbf{2 0 0 0}$ & $\mathbf{2 0 1 0}$ & $\mathbf{2 0 1 9}$ \\
\hline Mean & $\$ 19.44$ & $\$ 26.35$ & $\$ 30.29$ & $\$ 20.64$ & $\$ 28.17$ & $\$ 35.22$ \\
\hline Standard Error of Mean & 0.11 & 0.06 & 0.07 & 0.49 & 0.23 & 0.26 \\
\hline Median & $\$ 16.03$ & $\$ 20.99$ & $\$ 24.28$ & $\$ 15.44$ & $\$ 20.75$ & $\$ 25.30$ \\
\hline Sample Size (N) & 17,225 & 97,308 & 103,865 & 1,122 & 9,742 & 11,006 \\
\hline
\end{tabular}

*Data Source: U.S. Census: 2000, 2010, 2019 | Display \& Calculation: Author's own work.

*U.S. Census 2000: Release Date - June 10, 2004 | Author Retrieved: September 15, 2021

*U.S. Census 2010: Release Date - October 12, 2011 | Author Retrieved: September 15, 2021

*U.S. Census 2020: Release Date - October 15, 2020 | Author Retrieved: September 15, 2021 
Data indicates that the foreign-born workers make more on average than U.S. born employees in the manufacturing industry. The data also shows the median wage is higher for the U.S. born for the years 2000 and 2010, which aligns with literature suggesting that the native born are likely to move to other labor markets that are not directly affected by immigration and where, presumably, wages could drop (Borjas and Edo, 2021). To explain why this is the case, regression analysis is needed to determine if any bias exists among the two groups. This paper presents a comprehensive model to determine the wages in the manufacturing industry while controlling for several individual characteristics and pointing out any differences among these two groups. The findings are useful validation for policy makers to ease immigration policy and/or the visa entry into the USA. The paper has three additional sections: methodology, results, and conclusion.

\section{Methodology}

To determine the employee wages in the manufacturing industry this paper applies and utilizes the earning equation that is primarily and widely used in labor economics literature (Mincer, 1958; Mincer, 1974; Lemieux, 2006; Weng et al., 2019). After the model is established, the paper utilizes the Oaxaca-Blinder decomposition method to point out any bias or differences between the two groups in the study, another widely used method that still works a benchmark in differences and bias across various disciplines in research (Oaxaca, 1973; Blinder, 1973; Averkamp, at al., 2020; Koh at al., 2020; Rahimi \& Nazari 2021; An \& Glynn, 2021).

\section{III.1 The Equation}

The equation is based on the Mincer (1974) earning function which states that years of schooling and potential experience are the determinants of wage earnings. This function continues to be a benchmark when it comes to wage earnings based on human capital—such as years of schooling and work experience.

Building on this model and given the nature of our analysis, in addition to schooling and potential work experience in this research are added several characteristics to the equation, such as marital status, gender, race, regions, and the occupation category for everyone in the dataset. The dependent variable is the natural log of the hourly wage earned. The natural log, similar to Mincer (1974) indicates that there is strong evidence to support the log earnings specification. 
The wage per hour is calculated from the dataset given three variables, income in the past 12 months divided by number of weeks worked divided by number of hours worked per week.

The experience variable is based on the calculation of potential work years, Age minus years of schooling minus 6. We follow a similar approach to Mincer (1958) original function but increase the number of years in school to recent research findings. According to the Shapiro et al. (2016), Witteveen and Attewell (2021) on average, accounting for any gaps in studies, it takes longer than four years to finish a bachelor's degree. The approach in this paper accounts for one additional year to everyone's degree type. The squared term of the potential work experience is like the Mincer (1974) equation and confirmed in recent literature, it shows the diminishing returns to years of work experience. Education in the Mincer equation suggests years of schooling, but more recent research, brings up the debate that the years of schooling overestimates some years and underestimates some other years depending on the year of schooling Lemieux (2003). Someone with 15 years of education and does not have a bachelor's degree is overestimated, while someone with 16 years of education and holds a bachelor's degree would be underestimated. To correct for this debate, this paper, in addition to years of schooling, uses degree type dummy variables for bachelors, masters, professional, and doctorate degrees.

The U.S. Bureau of Labor Statistics publishes average earnings by occupation and the data indicates differences among occupation categories, race, and regions in the country. To address these differences and be able to have a more comprehensive conclusion, this paper includes these variables in the equation. This paper also addresses the vast literature on gender wage discrimination, therefore the gender wage gap is included as a control for this discrimination/bias. Including the above-mentioned variables, we arrive at the equation.

$L_{n}(W)=\alpha+\beta_{1}(S)+\beta_{2}(\rho)+\beta_{3}\left(\rho^{2}\right)+\beta_{4}\left(\rho^{3}\right)+\beta_{5}(S E)+\beta_{6}(M)+\beta_{7}(G)+\beta_{8}^{i}(R E)+\beta_{9}^{j}(R)+\beta_{10}^{k}(S)+\beta_{11}^{h}(O C)+\varepsilon$

- $L_{n}(W)$ : Natural log of wages per hour (Dependent)

- $S$ : Number of years in school, we expect higher earning for each year of each additional year of education in school.

- SE: Vector - These are dummy variables representing, bachelor's, master's, professional, and doctorate degrees. Important to ensure that the standard Mincer equation does not 
overstate the year before graduation and/or understate the year after graduation (Lemieux 2006).

- $\rho$ : Individuals potential work experience \& $\rho^{2}$ is the squared term of individuals' potential work experience (we expect positive sign for $\rho$ as more years of experience the wages rise, we expect a negative sign for $\rho^{2}$ due to diminishing return to work experience, and $\rho^{3}$ research points out that we add higher order polynomials to fine-tune the standard Mincer model, otherwise the e equation will understate the wage growth for younger workers (Lemieux, 2006).

- M: Individuals marital status if person is married 1 if not 0 . Based on literature (Chiodo, 2002) we expect a positive sign for married individuals.

- G: Individuals Gender if person is female 1 if male 0. Based on literature (Schieder and Gould, 2016) we expect a negative sign, indicating that female employees make less than male.

- RE: Vector, the individual race and ethnicity, included: Hispanic, Black, Asian, \& Other Races; these dummy variables are set against the white race dummy variable. The values are 1 if the person is of $i$ race, 0 if the person is not. Any result here will be compared to white.

- R: Vector, the region where the individual employee works, included regions are midwest, south, \& west. The regions are set against the northeast region, results will be compared to the northeast region employees.

- OC: Vector - Occupation categories: Management, Office related work, Research and Analysis, Engineering, transportation, and other roles; these roles are compared to the production roles, the largest employment roles in the manufacturing industry.

- $\varepsilon$ : is the error term, the residuals not explained by the model (See appendix 3).

The $\beta_{n}$ coefficients show the percentage of impact on dependent variable $L_{n}(W)$, for each quality or characteristic included in the equation. The above equation will investigate separately the two groups, U.S. born and the foreign born at three separate time periods: 2000, 2010 and 2019. Thus, six linear regression results will provide us with each of the coefficients $\beta_{n}$.

\section{III.2 Oaxaca-Blinder Decomposition Methodology}

Oaxaca-Blinder (1973) decomposition is a method to analyze the wage differentials between two groups and determine the portion of the wage differential that is attributable to differences in education and experience and the portion that is potentially attributed to bias or discrimination 
toward one group (Oaxaca and Blinder 1973). We use this method to measure the differences between our two groups and the results from the above equation.

To best understand the model, we will consider the base of the equation, which is a white single male with less than a college degree living in the northeast and working in the production line in the manufacturing industry. This is the base for the equation model before additional characteristics are added to the model. The equation for this sub-subgroup of individuals takes the following form, as the rest of the variables are zero. The same function is applied to both groups, U.S. born and foreign born.

$$
\begin{array}{ll}
\text { U.S. born (u): } & L_{u}(W)=\alpha_{u}+\beta_{1 u}\left(S_{u}\right)+\beta_{2 u}\left(\rho_{u}\right)+\beta_{3 u}\left(\rho_{u}{ }^{2}\right)+\beta_{4 u}\left(\rho_{u}{ }^{3}\right) \\
\text { Foreign born (f): } & L_{f}(W)=\alpha_{f}+\beta_{1 f}\left(S_{f}\right)+\beta_{2 f}\left(\rho_{f}\right)+\beta_{3 f}\left(\rho_{f}{ }^{2}\right)+\beta_{4 f}\left(\rho_{u}{ }^{3}\right)
\end{array}
$$

\section{Potential bias differences equation ( $\Omega$ ):}

$$
\Omega=\left(\alpha_{u}-\alpha_{f}\right)+\left(\beta_{1 u}-\beta_{1 f}\right)\left(S_{f}\right)+\left(\beta_{2 u}-\beta_{2 f}\right)\left(\rho_{f}\right)+\left(\beta_{3 u}+\beta_{3 f}\right)\left(\rho_{f}^{2}\right)+\left(\beta_{4 u}+\beta_{4 f}\right)\left(\rho_{f}^{3}\right)
$$

The results in the above equation will show the potential bias towards the subgroup mentioned above. To compare the same subgroup with a college or higher degree the equation takes the following form. We only need to take the differences in coefficients for each attribute since the dummy variable only takes two values of 1 or 0 .

$$
\Omega=\left(\alpha_{u}-\alpha_{f}\right)+\left(\beta_{1 u}-\beta_{1 f}\right)\left(S_{f}\right)+\left(\beta_{2 u}-\beta_{2 f}\right)\left(\rho_{f}\right)+\left(\beta_{3 u}-\beta_{3 f}\right)\left(\rho_{f}^{2}\right)+\left(\beta_{4 u}-\beta_{4 f}\right)\left(\rho_{f}^{3}\right)++\left(\beta_{5 u}-\beta_{5 f}\right)(1)
$$

To expand the subgroup to include other races, regions, occupation categories, we just subtract the coefficients from each other. The next section shows the results of the equation and the potential bias differences.

\section{Results}

The regression equation analyzes the data for the three periods for each group, U.S. born vs. foreign born workers. The table 5 below shows six regression outputs, for the U.S. Census years 2000, 2010, 2019. 
Table 5:

Regression Model Output - The Manufacturing Industry - Log Hourly Wage Dependent Variable

\begin{tabular}{|c|c|c|c|c|c|c|c|c|c|c|c|c|}
\hline \multirow{3}{*}{$\begin{array}{l}\text { Variables used in the } \\
\text { regression model: The } \\
\text { Manufacturing Industry }\end{array}$} & \multicolumn{6}{|c|}{ U.S. Born } & \multicolumn{6}{|c|}{ Foreign Born } \\
\hline & \multicolumn{2}{|c|}{ Year 2000} & \multicolumn{2}{|c|}{ Year 2010} & \multicolumn{2}{|c|}{ Year 2019} & \multicolumn{2}{|c|}{ Year 2000} & \multicolumn{2}{|c|}{ Year 2010} & \multicolumn{2}{|c|}{ Year 2019} \\
\hline & B & Sig & $\beta$ & Sig & ß & Sig & $\beta$ & Sig & $\beta$ & Sig & $\beta$ & Sig \\
\hline (Constant) & 1.798 & $* * *$ & 1.920 & $* * *$ & 2.211 & $* * *$ & 2.224 & $* * *$ & 2.297 & $* * *$ & 2.458 & $* * *$ \\
\hline Years of Schooling & 0.038 & $* * *$ & 0.041 & $* * *$ & 0.031 & $* * *$ & 0.026 & $* * *$ & 0.016 & $* * *$ & 0.013 & $* * *$ \\
\hline $\begin{array}{l}\text { Potential years of work } \\
\text { experience }\end{array}$ & 0.037 & $* * *$ & 0.041 & $* * *$ & 0.032 & $* * *$ & -0.003 & - & 0.043 & $* * *$ & 0.042 & $* * *$ \\
\hline $\begin{array}{l}\text { Potential years of work } \\
\text { experience (Squared) }\end{array}$ & -0.001 & $* * *$ & -0.001 & $* * *$ & -0.001 & $* * *$ & 0.001 & - & -0.001 & $* * *$ & -0.001 & $* * *$ \\
\hline $\begin{array}{l}\text { Potential years of work } \\
\text { experience (Cubed) }\end{array}$ & 0.000 & $* * *$ & 0.000 & $* * *$ & 0.000 & $* * *$ & 0.000 & - & 0.000 & $* * *$ & 0.000 & $* * *$ \\
\hline Bachelor's degree & 0.180 & $* * *$ & 0.186 & $* * *$ & 0.226 & $* * *$ & 0.202 & $* * *$ & 0.270 & $* * *$ & 0.234 & $* * *$ \\
\hline Master's Degree & 0.288 & $* * *$ & 0.316 & $* * *$ & 0.394 & $* * *$ & 0.408 & $* * *$ & 0.447 & $* * *$ & 0.467 & $* * *$ \\
\hline Profes sional Degree & 0.281 & $* * *$ & 0.566 & $* * *$ & 0.545 & $* * *$ & 0.291 & - & 0.477 & $* * *$ & 0.565 & $* * *$ \\
\hline Doctorate Degree & 0.328 & $* * *$ & 0.443 & $* * *$ & 0.482 & $* * *$ & 0.559 & $* * *$ & 0.649 & $* * *$ & 0.648 & $* * *$ \\
\hline Married 1 , Not married 0 & 0.085 & $* * *$ & 0.092 & $* * *$ & 0.121 & $* * *$ & 0.076 & - & 0.038 & $* * *$ & 0.058 & $* * *$ \\
\hline $0=$ Male $.1=$ Female & -0.240 & $* * *$ & -0.187 & $* * *$ & -0.181 & $* * *$ & -0.256 & $* * *$ & -0.162 & $* * *$ & -0.150 & $* * *$ \\
\hline Hispanic Ethnicity & 0.008 & - & -0.034 & $* * *$ & -0.052 & $* * *$ & -0.117 & - & -0.106 & $* * *$ & -0.138 & $* * *$ \\
\hline Black Race Alone & -0.025 & $* *$ & -0.074 & $* * *$ & -0.095 & $* * *$ & 0.084 & - & -0.104 & $* * *$ & -0.120 & $* * *$ \\
\hline Asian Race Alone & 0.069 & - & 0.052 & $* * *$ & 0.021 & $*$ & -0.098 & $* * *$ & -0.068 & $* * *$ & -0.080 & $* * *$ \\
\hline Other Races & -0.037 & - & -0.053 & $* * *$ & -0.057 & $* * *$ & -0.046 & - & -0.082 & $* * *$ & -0.018 & - \\
\hline Midwest region & -0.012 & - & -0.068 & $* * *$ & -0.047 & $* * *$ & 0.017 & - & -0.068 & $* * *$ & -0.087 & $* * *$ \\
\hline South region & -0.074 & $* * *$ & -0.049 & $* * *$ & -0.040 & $* * *$ & -0.036 & - & -0.095 & $* * *$ & -0.126 & $* * *$ \\
\hline West region & 0.018 & - & 0.075 & $* * *$ & 0.066 & $* * *$ & 0.064 & $*$ & 0.025 & * & 0.046 & $* * *$ \\
\hline MGR Occupations & 0.427 & $* * *$ & 0.430 & $* * *$ & 0.463 & $* * *$ & 0.597 & $* * *$ & 0.601 & $* * *$ & 0.660 & $* * *$ \\
\hline Researchers, Analysts & 0.255 & $* * *$ & 0.281 & $* * *$ & 0.300 & $* * *$ & 0.308 & $* * *$ & 0.362 & $* * *$ & 0.434 & $* * *$ \\
\hline CMM Occupations & 0.355 & $* * *$ & 0.370 & $* * *$ & 0.407 & $* * *$ & 0.553 & $* * *$ & 0.513 & $* * *$ & 0.584 & $* * *$ \\
\hline ENGN Occupations & 0.272 & $* * *$ & 0.295 & $* * *$ & 0.354 & $* * *$ & 0.346 & $* * *$ & 0.430 & $* * *$ & 0.486 & $* * *$ \\
\hline OFF Occupations & 0.046 & $* * *$ & 0.028 & $* * *$ & 0.055 & $* * *$ & 0.132 & $* *$ & 0.106 & $* * *$ & 0.117 & $* * *$ \\
\hline TRN Occupations & -0.070 & $* * *$ & -0.081 & $* * *$ & -0.084 & $* * *$ & -0.108 & - & -0.066 & $* *$ & -0.046 & $* *$ \\
\hline Other occupations & 0.114 & $* * *$ & 0.137 & $* * *$ & 0.158 & $* * *$ & 0.219 & $* * *$ & 0.246 & $* * *$ & 0.215 & *** \\
\hline \multicolumn{13}{|l|}{$\begin{array}{l}* \text { Indicates significant at } 10 \% \\
* * \text { Indicates significant at } 5 \% \\
* * * \text { Indicates significant at } 1 \%\end{array}$} \\
\hline R Square & 0.425 & & 0.469 & & 0.477 & & 0.574 & & 0.555 & & 0.584 & \\
\hline Durbin-Watson & 1.921 & & 1.944 & & 1.924 & & 1.87 & & 1.934 & & 1.936 & \\
\hline $\mathrm{N}$ & 16,476 & & 92,453 & & 98,287 & & 863 & & 7,639 & & 8,792 & \\
\hline
\end{tabular}

*Data Source: U.S. Census: 2000, 2010, 2019 | Display \& Calculation: Author's own work.

*U.S. Census 2000: Release Date - June 10, 2004 | Author Retrieved: September 15, 2021

*U.S. Census 2010: Release Date - October 12, 2011 | Author Retrieved: September 15, 2021

*U.S. Census 2020: Release Date - October 15, 2020 | Author Retrieved: September 15, 2021 
The regression results indicate that the Mincer (1974) equation still provides a benchmark for wage earnings and that an individual's human capital, such schooling and work experience, are the primary driver. Consistent with literature (Mincer, 1958, 1974; Heckman et al., 2005; Lemieux, 2006, Weng et al., 2019). In our data, the model is significant across all years and groups. The experience is significant in 5 out of 6 regressions, except for year 2000 for the foreign group, in which the coefficients are insignificant. The two subsections below show a regression summary and any potential bias between the two groups.

\section{IV.1 Summary of regression results: Manufacturing industry labor force}

Consistent with literature, the significant coefficients carry the expected signs for the manufacturing industry labor force. The results confirm that the years of schooling have a positive impact on earnings, each additional year of schooling results in $1.3 \%$ to $4.1 \%$ of higher wages at the start of work experience, interesting results are that for the U.S. born the years of schooling have a much higher impact than for foreign born. However, for the foreign born, the degree coefficients demonstrate slightly higher earning at the start of work experience. Results indicate that for the year 2019, a U.S. born worker would make $22.6 \%$ more if he/she had a bachelor's degree than anotherU.S. born who does not have a bachelor's degree. While foreign born workers with a bachelors' degree would make $23.4 \%$ more than a foreign born without a bachelor's degree.

Results show that for each year of additional work experience the wages rise by $3.2 \%$ to $4.2 \%$, and the results are similar between the U.S. born and foreign born. The experience square shows a negative sign very low coefficient, which confirms the diminishing returns expectations. Married individuals continue to make more than singles, for the year 2000 results are like Chiodo (2002) but the difference between married and unmarried have shrank in the past 20 years; in the year 2019 married individuals make only 1.2\% more for the U.S. born group and 5.8\% more for the foreign-born group. Females in the manufacturing industry continue to earn less, while these percentages have improved the coefficients indicate that U.S. born females continue to earn $18 \%$ less than U.S. born males, and foreign-born females continue to earn $15 \%$ less than foreign born males. Results indicate that Hispanic and black individuals make on average less than their white counterparts based on the model, and the results show that in the manufacturing industry these results have worsened from the year 2000--a finding that is consistent with current literature (Daly at al., 2020). As for regions, employees in the manufacturing industry seem to 
have the highest earnings in the west regions, while the midwest and south region employees earn less than the northeast base region. Manufacturing employees working in management, research, office, computer operators, and engineers earn more than the base which are the production workers, employees in the transportation area of manufacturing earn the least in the industry.

\section{IV.1 Oaxaca-Blinder decomposition in the manufacturing industry}

The base of the model is - white male employee - located in the northeast - working in the production occupation--does not have a bachelor's degree - and is not married.

The Oaxaca-Blinder results indicate that in the year 2000 the U.S. born (individual identified above) earned on average $6.2 \%$ more than the foreign born while having the same work experience and years of education. These bias started dissipating in 2019 is at $0.93 \%$.

- 2000: 6.20\% U.S. Born earning bias

- 2010: 5.64\% U.S. Born earning bias

- 2019: 0.93\% U.S. Born earning bias

If we were to analyze the individual but add a bachelor's degree we find the U.S. born in the year 2000 earned 4.01\% more than the foreign born with a bachelor's degree. In the year 2010, the U.S. born actually made $2.69 \%$ less than the foreign born, and in 2019 it is almost identical with U.S. born making $0.18 \%$ more on average.

- 2000: 4.01\% U.S. Born earning bias

- 2010: -2.69\% U.S. Born earning bias

- 2019: 0.18\% U.S. Born earning bias

The results above can be used to compare any individual within the given occupation category, education, region, marital status, gender and race, by applying the Oaxaca-Blinder decomposition. Regression output and the Oaxaca-Blinder method confirm that there is no bias towards any groups by the year 2019 for either educated and less educated employees in the manufacturing industry. 


\section{Limitations}

Even though this paper has focused the research to one industry and included several characteristics that do have an impact on earnings, there are additional factors' that determine wages such as length of time at one company or doing the same job, which the American Community Survey does not measure. Also, even though we looked at the natural log of wages, the data reported has potential for errors, as several people in the country do more than one job, therefore the reporting could have been understating or overstating. The U.S. Census 2000 is the first year such data was reported, and the sample size was smaller in comparison to the 2010 and 2019.

\section{Conclusion}

The manufacturing industry, being the largest employer and having a large share of foreign-born employees in their payroll, is in the brink of a disadvantage globally, due to aging current employees and the demand for highly skilled labor force. The key finding in this research shows that there is no bias toward either group, U.S born vs. foreign-born, a finding that demonstrates that the manufacturing industry in the U.S. does not favor any group based on birth origin. This finding is both attractive and provides competitiveness for skilled employees within and outside the country.

Data shows those holding a bachelor's degree or higher make between $28-37 \%$ of the employment in the manufacturing industry. This data is a clear indicator that a qualified educated labor force is required for the industry to be competitive on the global stage and such a labor force that the manufacturers will have to look beyond U.S. borders.

The results confirm that the higher earnings from foreign born employees (Table 4) in the manufacturing industry is due to human capital advantage, on average more years of schooling and more years of work experience. The findings align with previous research stating that foreign born have higher incentives to complete more years of education (Borjas, 1982). The results also 
indicate that, in recent years, the bias towards the two groups has nearly diminished. Therefore, for the U.S. to continue to have a competitive manufacturing industry, it must simplify and ease the restrictions in labor hirings. The industry needs a qualified labor force as the U.S. remains a desired location for educated skilled labor. The findings show no bias, so the desire is supported by evidence that the U.S. has the tools to attract the needed talent. Loosening the H1-B visa restrictions will allow the manufacturing industry to attract talent across the globe, and these individuals will have well paid jobs thus resulting in higher tax revenue as well.

The results demonstrate that by 2019 the industry posed little to no bias towards either of the groups, U.S. born vs. foreign-born. The data trends show shifts towards higher demand for skilled labor force in the manufacturing industry. The evidence demonstrates the need for policy makers to loosen the immigration policy and attract talent beyond U.S. borders, especially increasing/or eliminating the cap restrictions on H1-B visas. 


\section{Declaration}

\section{Ethics approval and consent to participate}

This study uses individual data made available by the U.S. Census Bureau to all researchers. The ACS PUMS files are a set of records from individual people or housing units, with disclosure protection enabled so that individuals or housing units cannot be identified.

"The Census Bureau has created these data to exclude information that would directly identify respondents and characteristics that may lead to the identification of respondents. The Census Bureau provides these data to facilitate statistical research and analysis." https://www.census.gov/data/developers/about/terms-of-service.html

\section{Consent for publication}

I, Erjon Gjoci, give my consent for the publication of "Empirical evidence against U.S. H1-B visa restrictions, the case of employment in the manufacturing industry" research paper to the Journal for Labour Market Research.

\section{Availability of data and materials}

Data is available to all researchers. PUMS files on the File Transfer Protocol (FTP) site are available in CSV and SAS formats. PUMS data prior to 2005 can also be found on our FTP site. Microdata access from 2005-current is available on data.census.gov.

\section{Competing Interests}

Not applicable.

\section{Funding}

Not applicable

\section{Author Contribution}

I, Erjon Gjoci, am the sole author and $100 \%$ of this material is my work.

\section{Acknowledgement}

I thank my wife and kids for their insights to ensure that this paper makes sense to everyone

\section{Author Information}

Erjon Gjoci

Senior Researcher

gjocierjon@gmail.com 


\section{References:}

An W, N. Glynn A. Treatment Effect Deviation as an Alternative to Blinder-Oaxaca Decomposition for Studying Social Inequality. Sociological Methods \& Research. 2021;50(3):1006-1033. doi:10.1177/0049124119852387

Averkamp, D., Bredemeier, C., \& Juessen, F. (2020). Decomposing Gender Wage Gaps: A Family Economics Perspective.

Blinder, A. S. (1973). Wage discrimination: Reduced form and structural estimates. The Journal of Human Resources, 8(7):436455.

Borjas, G. J., \& Edo, A. (2021). Gender, Selection into Employment, and the Wage Impact of Immigration (No. w28682). National Bureau of Economic Research.

Borjas, G. J. (1982). The earnings of male Hispanic immigrants in the United States. ILR Review, 35(3), 343-353.

Card, D., Lemieux, T., \& Riddell, W. C. (2003). Unionization and wage inequality: a comparative study of the US, the UK, and Canada.

Carneiro, P., Hansen, K. T., \& Heckman, J. J. (2003). Estimating Distributions of Treatment Effects with an Application to the Returns to Schooling and Measurement of the Effects of Uncertainty on College.

Chiodo, A. J., \& Owyang, M. T. (2002). For love or money: Why married men make more. The Regional Economist, 2.

Daly, M. C., Hobijn, B., \& Pedtke, J. H. (2020). Labor market dynamics and black-white earnings gaps. Economics Letters, 186, 108807.

Eckstein, S., \& Peri, G. (2018). Immigrant niches and immigrant networks in the US labor market. RSF: The Russell Sage Foundation Journal of the Social Sciences, 4(1), 1-17.

Gould, E., Schieder, J., \& Geier, K. (2016). What is the gender pay gap and is it real?. Economic Policy Institute.

Justin Gest (2021). Projections Show Increasing Future Immigration Grows the U.S. Competitive

Advantage. fwd.us. https://www.fwd.us/wp-content/uploads/2021/02/GMU_V7.pdf

Koh, Keumseok, Michelle L. Kaiser, Glennon Sweeney, Karima Samadi, and Ayaz Hyder. (2020). "Explaining Racial Inequality in Food Security in Columbus, Ohio: A Blinder-Oaxaca Decomposition Analysis" International Journal of Environmental Research and Public Health 17, no. 15: 5488. https://doi.org/10.3390/ijerph17155488

Lagakos, D., Moll, B., Porzio, T., Qian, N., \& Schoellman, T. (2018). Life cycle wage growth across countries. Journal of Political Economy, 126(2), 797-849.

Lang, Kevin, and Jee-Yeon K. Lehmann. 2012. "Racial Discrimination in the Labor Market: Theory and Empirics." Journal of Economic Literature, 50 (4): 959-1006.DOI: 10.1257/jel.50.4.959

Lemieux, T. (2006). Postsecondary education and increasing wage inequality. American Economic Review, 96(2), 195-199.

Manufacturing Business Outlook Survey. (September 2021). Philadelphia Federal Reserve Bank.

Mayda, A. M., Ortega, F., Peri, G., Shih, K., \& Sparber, C. (2018). The effect of the H-1B quota on the employment and selection of foreign-born labor. European Economic Review, 108, 105-128.

Mincer, J. (1958). Investment in human capital and personal income distribution. Journal of political economy, 66(4), 281-302.

Mincer, J. (1974). Schooling, Experience, and Earnings. Human Behavior \& Social Institutions No. 2. 
Oaxaca, R. (1973). Male-female wage differentials in urban labor markets. International economic review, 693709.

Rahimi, E., \& Hashemi Nazari, S. S. (2021). A detailed explanation and graphical representation of the BlinderOaxaca decomposition method with its application in health inequalities. Emerging Themes in Epidemiology, 18(1), 1-15.

Sapio Research (2021). The 2021 study of digital transformation in the manufacturing. Report commissioned by Sana Commerce. https://www.sana-commerce.com/the-manufacturing-ecommerce-benchmark-report/

Shapiro, D., Dundar, A., Wakhungu, P. K., Yuan, X., Nathan, A., \& Hwang, Y. (2016). Time-to-degree: A national view of the time enrolled and elapsed for associate and bachelor's degree earners (signature report no. 11). National Student Clearinghouse Research Center.

Shapiro, J. P., \& Stefkovich, J. A. (2016). Ethical leadership and decision making in education: Applying theoretical perspectives to complex dilemmas. Routledge.

Weng, P., Yuan, L., Li, C., Yi, C., \& Zhang, Y. (2019). Estimation of the Rate of Return to Higher Education Based on Least Squares Method and Mincer Equation Model.

Witteveen, D., Attewell, P. (2021). Delayed Time-to-Degree and Post-college Earnings. Res High Educ 62, 230257. https://doi.org/10.1007/s11162-019-09582-8

U.S. Census Bureau. (2000). 2000 American Community Survey 1-year Public Use Microdata Samples [CSV Data file]. Retrieved from: https://www.census.gov/programs-surveys/acs/microdata/access.html

U.S. Census Bureau. (2010). 2010 American Community Survey 1-year Public Use Microdata Samples [SAS Data file]. Retrieved from: https://www.census.gov/programs-surveys/acs/microdata/access.html

U.S. Census Bureau. (2019). 2019 American Community Survey 1-year Public Use Microdata Samples [SAS Data file]. Retrieved from https://www.census.gov/programs-surveys/acs/microdata/access.html 
Appendix 1: Dataset Frequency and Yearly Wages

\begin{tabular}{|c|c|c|c|c|c|c|c|c|c|c|}
\hline \multirow{2}{*}{\begin{tabular}{|l|} 
Dataset \\
Frequency \\
\end{tabular}} & \multicolumn{4}{|c|}{2000} & \multicolumn{4}{|c|}{2000} & \multicolumn{2}{|c|}{2000} \\
\hline & & $\mathrm{N}$ & & $\%$ & & $\mathrm{~N}$ & & $\%$ & $\mathrm{~N}$ & $\%$ \\
\hline USBORN & & 17225 & & $93.9 \%$ & & 97308 & & $90.9 \%$ & 103865 & $90.4 \%$ \\
\hline FOREIGN BORN & & 1122 & & $6.1 \%$ & & 9742 & & $9.1 \%$ & 11006 & $9.6 \%$ \\
\hline \multirow[b]{2}{*}{ US BORN } & \multicolumn{2}{|r|}{ Mean } & \multicolumn{2}{|c|}{$\begin{array}{c}\text { Standard Error } \\
\text { of Mean }\end{array}$} & \multicolumn{2}{|r|}{ Median } & \multicolumn{2}{|r|}{ Mode } & $\begin{array}{c}\text { Weeks } \\
\text { worked past } \\
12 \text { months } \\
\text { (Mean) }\end{array}$ & $\begin{array}{c}\text { Hours } \\
\text { worked per } \\
\text { week } \\
\text { (Mean) } \\
\end{array}$ \\
\hline & $\$$ & $44,137.14$ & $\$$ & 263.42 & $\$$ & $35,648.06$ & $\$$ & $30,555.48$ & 51.3 & 43.5 \\
\hline FOREIGN BORN & $\$$ & $45,702.05$ & $\$$ & $1,172.36$ & $\$$ & $33,611.03$ & $\$$ & $30,555.48$ & 51.1 & 42.6 \\
\hline Total 2000 & $\$$ & $44,232.84$ & $\$$ & 257.50 & $\$$ & $35,648.06$ & $\$$ & $30,555.48$ & 51.3 & 43.5 \\
\hline \multicolumn{11}{|l|}{2010} \\
\hline US BORN & $\$$ & $58,672.54$ & $\$$ & 152.24 & $\$$ & $45,343.08$ & $\$$ & $40,304.96$ & 50.7 & 43.0 \\
\hline FOREIGN BORN & $\$$ & $61,059.57$ & $\$$ & 531.96 & $\$$ & $44,335.46$ & $\$$ & $30,228.72$ & 50.8 & 41.9 \\
\hline Total 2010 & $\$$ & $58,889.77$ & $\$$ & 146.63 & $\$$ & $45,343.08$ & $\$$ & $40,304.96$ & 50.7 & 42.9 \\
\hline \multicolumn{11}{|l|}{2019} \\
\hline USBORN & $\$$ & $69,069.55$ & $\$$ & 169.10 & $\$$ & $53,537.69$ & $\$$ & $50,507.25$ & 51.8 & 43.4 \\
\hline FOREIGN BORN & $\$$ & $78,442.61$ & $\$$ & 617.30 & $\$$ & $55,557.98$ & $\$$ & $40,405.80$ & 51.8 & 42.4 \\
\hline Total 2019 & $\$$ & $69,967.60$ & $\$$ & 164.14 & $\$$ & $54,547.83$ & $\$$ & $50,507.25$ & 51.8 & 43.3 \\
\hline
\end{tabular}

*Data Source: U.S. Census: 2000, 2010, 2019 | Display \& Calculation: Author's own work.

*U.S. Census 2000: Release Date - June 10, 2004 | Author Retrieved: September 15, 2021

*U.S. Census 2010: Release Date - October 12, 2011 | Author Retrieved: September 15, 2021

*U.S. Census 2020: Release Date - October 15, 2020 | Author Retrieved: September 15, 2021

Appendix 2: Percentage of U.S. Labor Force Employment by Industry

\begin{tabular}{|c|c|c|c|c|c|c|c|c|c|c|c|c|}
\hline \multirow[b]{2}{*}{ Industry } & \multicolumn{4}{|c|}{2000} & \multicolumn{4}{|c|}{2010} & \multicolumn{4}{|c|}{2019} \\
\hline & US BORN & $\begin{array}{c}\text { FOREIGN } \\
\text { BORN }\end{array}$ & Total N & Total \% & US BORN & $\begin{array}{c}\text { FOREIGN } \\
\text { BORN }\end{array}$ & Total N & Total \% & US BORN & $\begin{array}{c}\text { FOREIGN } \\
\text { BORN }\end{array}$ & Total N & Total \% \\
\hline AGR & $0.6 \%$ & $0.5 \%$ & 519 & $0.6 \%$ & $0.8 \%$ & $0.7 \%$ & 5018 & $0.8 \%$ & $0.8 \%$ & $0.7 \%$ & 5757 & $0.8 \%$ \\
\hline EXT & $0.6 \%$ & $0.2 \%$ & 510 & $0.6 \%$ & $0.8 \%$ & $0.3 \%$ & 4866 & $0.7 \%$ & $0.7 \%$ & $0.3 \%$ & 5056 & $0.7 \%$ \\
\hline UTL & $1.2 \%$ & $0.4 \%$ & 1069 & $1.2 \%$ & $1.3 \%$ & $0.7 \%$ & 8275 & $1.3 \%$ & $1.1 \%$ & $0.6 \%$ & 8181 & $1.1 \%$ \\
\hline $\mathrm{CON}$ & $5.8 \%$ & $4.7 \%$ & 5225 & $5.8 \%$ & $5.3 \%$ & $3.7 \%$ & 33985 & $5.2 \%$ & $6.4 \%$ & $5.0 \%$ & 48002 & $6.3 \%$ \\
\hline MFG & $20.1 \%$ & $22.6 \%$ & 18347 & $20.2 \%$ & $16.2 \%$ & $17.8 \%$ & 107050 & $16.3 \%$ & $15.0 \%$ & $15.2 \%$ & 114871 & $15.0 \%$ \\
\hline WHL & $5.2 \%$ & $4.5 \%$ & 4694 & $5.2 \%$ & $4.0 \%$ & $3.8 \%$ & 26058 & $4.0 \%$ & $3.5 \%$ & $3.3 \%$ & 26848 & $3.5 \%$ \\
\hline RET & $13.3 \%$ & $10.7 \%$ & 11912 & $13.1 \%$ & $12.9 \%$ & $10.5 \%$ & 83178 & $12.7 \%$ & $12.0 \%$ & $9.6 \%$ & 90338 & $11.8 \%$ \\
\hline TRN & $4.1 \%$ & $3.6 \%$ & 3692 & $4.1 \%$ & $3.9 \%$ & $4.1 \%$ & 25681 & $3.9 \%$ & $4.4 \%$ & $5.1 \%$ & 34091 & $4.5 \%$ \\
\hline INF & $4.1 \%$ & $3.6 \%$ & 3665 & $4.0 \%$ & $3.0 \%$ & $2.6 \%$ & 19355 & $2.9 \%$ & $2.4 \%$ & $2.3 \%$ & 18367 & $2.4 \%$ \\
\hline FIN & $9.4 \%$ & $9.1 \%$ & 8485 & $9.4 \%$ & $9.3 \%$ & $9.0 \%$ & 61135 & $9.3 \%$ & $8.7 \%$ & $8.8 \%$ & 66366 & $8.7 \%$ \\
\hline PRF & $9.6 \%$ & $10.0 \%$ & 8727 & $9.6 \%$ & $11.2 \%$ & $12.3 \%$ & 73914 & $11.3 \%$ & $12.8 \%$ & $14.2 \%$ & 98657 & $12.9 \%$ \\
\hline EDU & $3.3 \%$ & $2.7 \%$ & 2963 & $3.3 \%$ & $4.3 \%$ & $3.2 \%$ & 27465 & $4.2 \%$ & $4.1 \%$ & $3.4 \%$ & 30746 & $4.0 \%$ \\
\hline MED & $11.5 \%$ & $12.7 \%$ & 10464 & $11.5 \%$ & $14.9 \%$ & $17.0 \%$ & 99241 & $15.1 \%$ & $14.7 \%$ & $16.8 \%$ & 114080 & $14.9 \%$ \\
\hline SCA & $1.3 \%$ & $0.9 \%$ & 1185 & $1.3 \%$ & $1.8 \%$ & $1.8 \%$ & 12026 & $1.8 \%$ & $1.9 \%$ & $2.1 \%$ & 14971 & $2.0 \%$ \\
\hline ENT & $5.7 \%$ & $8.5 \%$ & 5287 & $5.8 \%$ & $6.1 \%$ & $7.9 \%$ & 40878 & $6.2 \%$ & $7.2 \%$ & $8.2 \%$ & 55963 & $7.3 \%$ \\
\hline SRV & $4.3 \%$ & $5.2 \%$ & 3929 & $4.3 \%$ & $4.3 \%$ & $4.6 \%$ & 28312 & $4.3 \%$ & $4.3 \%$ & $4.4 \%$ & 32707 & $4.3 \%$ \\
\hline
\end{tabular}

*Data Source: U.S. Census: 2000, 2010, 2019 | Display \& Calculation: Author's own work.

*U.S. Census 2000: Release Date - June 10, 2004 | Author Retrieved: September 15, 2021

*U.S. Census 2010: Release Date - October 12, 2011 | Author Retrieved: September 15, 2021

*U.S. Census 2020: Release Date - October 15, 2020 | Author Retrieved: September 15, 2021 


\section{Appendix 3: Standardized Residual Histogram}

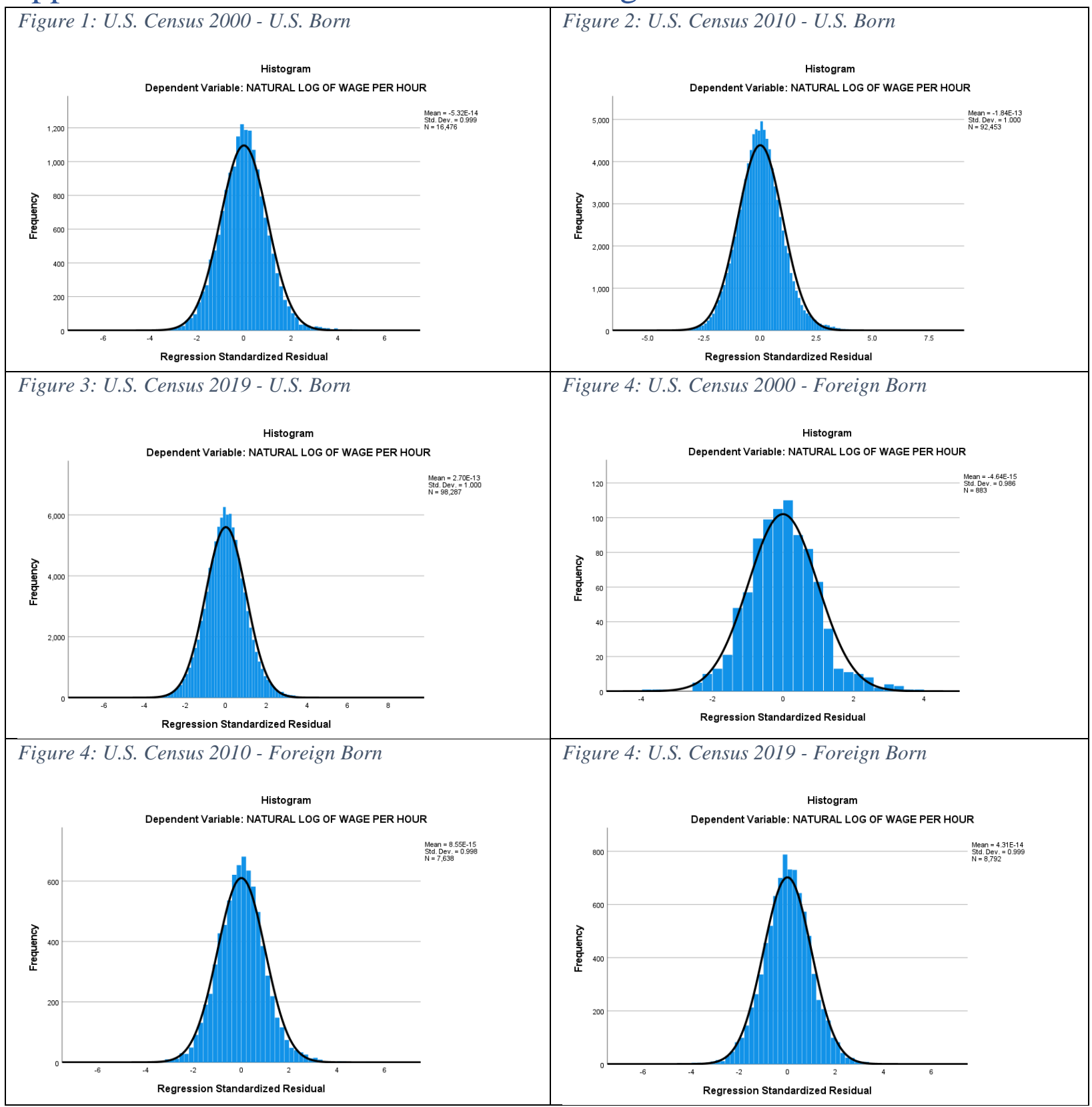

*Data Source: U.S. Census: 2000, 2010, 2019 | Display \& Calculation: Author's own work.

*U.S. Census 2000: Release Date - June 10, 2004 | Author Retrieved: September 15, 2021

*U.S. Census 2010: Release Date - October 12, 2011 | Author Retrieved: September 15, 2021

*U.S. Census 2020: Release Date - October 15, 2020 | Author Retrieved: September 15, 2021 